\title{
Development of a new PVC composition with reduced combustibility
}

\author{
Authors: \\ Aliya K. Mazitova, \\ Professor, Head of Applied and Natural Sciences Department, Ufa State Petroleum Technological University, \\ Ufa, Bashkortostan Republic, Russia, elenaasf@yandex.ru; \\ Irina N. Vikhareva, \\ Assistant, Applied and Natural Sciences Department, Ufa State Petroleum Technological University, \\ Ufa, Bashkortostan Republic, Russia, vikhir@yandex.ru; \\ II'naz I. Zaripov, \\ Undergraduate, Applied and Natural Sciences Department, Ufa State Petroleum Technological University, \\ Ufa, Bashkortostan Republic, Russia, ilnaz.zaripov1996@mail.ru; \\ Ruslan M. Mazitov, \\ Associate Professor, Department of History and Cultural Studies, Ufa State Petroleum Technological University, \\ Ufa, Bashkortostan Republic, Russia, mazitovps@mail.ru; \\ Vladimir I. Kanareikin, \\ Associate Professor, Applied and Natural Sciences Department, Ufa State Petroleum Technological University, \\ Ufa, Bashkortostan Republic, Russia, kanareikina1948@mail.ru
}

Abstract: Polyvinyl chloride (PVC) is one of the mostly plasticized polymers. The plasticizers used in this case are esters of aromatic or aliphatic acids with linear or branched aliphatic alcohols with a moderate chain length. Among them, phthalates (orthophthalic acid esters with fatty alcohols) have the widest range of applications among aromatic acid esters. They are characterized by excellent compatibility not only with PVC, but also with a number of other polymers, possess good physical and mechanical properties, but are toxic compounds. Therefore, their use is gradually being replaced by low-toxic and non-toxic plasticizers.

Adipic acid esters which are widely used are environmentally safe. However, their use in plastic compounds for cable products requires the introduction of special additives - flame retardants.

The results of the development of a low combustible PVC formulation are described herein. The dibutoxyethyl adipate developed by us was used as a plasticizer, and industrial di-(2-ethylhexyl) phenyl phosphate - as a flame retardant.

First of all, we obtained an ester of adipic acid and ethoxylated butanol with a degree of ethoxylation of 5. Conditions of its production with maximum yield are selected. The physical and chemical properties of the synthesized compound were studied. Formulations of PVC compositions based on the obtained adipate with various amounts of di-(2-ethylhexyl) phenyl phosphate were compiled. Flammability tests of PVC compounds are presented. The combustible characteristics of the cable plastic samples using the developed plasticizers comply with state standard 5960-72 with changes 3-9. The best results were obtained by using phosphorus-containing additive in an amount of $3 \mathrm{wt} \%$. It is shown that small amounts of di-(2-ethylhexyl) phenyl phosphate provide fire-fighting properties.

Keywords: adipic acid, adipate, cable plasticate, combustibility, esterification, ethoxylation, ethoxylated butanol, flame retardant, plasticizer of polyvinyl chloride, phosphorus-containing plasticizer.

For citation: Mazitova A.K., Vikhareva I.N., Zaripov I.I., Mazitov R.M., Kanarekin V.I. Development of a new PVC composition with reduced flammability Nanotehnologii v stroitel'stve = Nanotechnologies in Construction. 2019, Vol. 11, no. 6, pp. 696-705. DOI: 10.15828/2075-8545-2019-11-6-696-705.

Machine-readable information on CC-licenses (HTML-code) in metadata of the paper

$<$ a rel="license" href="http://creativecommons.org/licenses/by/4.0/" ><img alt="Creative Commons License" style="border-width:0" src="https://i.creativecommons.org///by/4.0/88x31.png"/></a $><$ br / $><$ span xmlns:dct="http://purl.org/dc/terms/" href="http://purl.org/dc/dcmitype/Text" property="dct:title" rel="dct:type" $>$ Development of a new PVC composition with reduced flammability $</$ span $>$ by $<$ a xmlns:cc="http://creativecommons.org/ns\#" href="Nanotehnologii v stroitel'stve = Nanotechnologies in Construction. 2019, Vol. 11, no. 6, pp. 696-705. DOI:10.15828/2075-8545-2019-11-6-696-705." property="cc:attributionName" re I="cc:attributionURL">Mazitova A.K., Vikhareva I.N., Zaripov I.I., Mazitov R.M., Kanarekin V.I.</a $>$ is licensed under a $<$ a rel="license" href="http://creativecommons. org/licenses/by/4.0/">Creative Commons Attribution 4.0 International License</a $>$.<br/>Based on a work at $<$ a xmlns:dct="http://purl.org/dc/terms/" href="http:// nanobuild.ru/en_EN/nanobuild-6-2019/" rel="dct:source" $>$ http://nanobuild.ru/en_EN/nanobuild-6-2019/</a $>.<$ br $/>$ Permissions beyond the scope of this license may be available at <a xmlns:cc="http://creativecommons.org/ns\#" href="vikhir@yandex.ru" rel="cc:morePermissions" $>$ vikhir@yandex.ru</a $>$. 


\section{Разработка новой ПВХ-композиции с пониженной горючестью}

\section{Авторы:}

Мазитова Алия Карамовна,

профессор, зав. каф. «Прикладные и естественнонаучные дисциплины», ФГБОУ ВО «Уфимский государственный нефтяной технический университет», г. Уфа, Республика Башкортостан, Россия, elenaasf@yandex.ru;

\section{Вихарева Ирина Николаевна,}

ассистент каф. «Прикладные и естественнонаучные дисциплины», ФГБОУ ВО «Уфимский государственный нефтяной технический университет», г. Уфа, Республика Башкортостан, Россия, vikhir@yandex.ru;

\section{Зарипов Ильназ Ильгизович,}

магистрант каф. «Прикладные и естественнонаучные дисциплины», ФГБОУ ВО «Уфимский государственный нефтяной технический университет», г. Уфа, Республика Башкортостан, Россия, ilnaz.zaripov1996@mail.ru;

\section{Мазитов Руслан Мидхатович,}

доцент кафедры истории и культурологи, ФГБОУ ВО «Уфимский государственный нефтяной технический университет», г. Уфа, Республика Башкортостан, Россия, mazitovps@mail.ru;

\section{Канарейкин Владимир Иванович,}

доцент каф. «Прикладные и естественнонаучные дисциплины», ФГБОУ ВО «Уфимский государственный нефтяной технический университет», г. Уфа, Республика Башкортостан, Россия, kanareikina1948@mail.ru

Резюме: Поливинилхлорид (ПВХ) является одним из полимеров, который чаще всего подвергается пластификации. Используемые при этом пластификаторы представляют собой сложные эфиры ароматических или алифатических кислот с линейными или разветвленными алифатическими спиртами с умеренной длинной цепью. Среди них фталаты (эфиры ортофталевой кислоты с жирными спиртами) имеют самый широкий спектр применения среди эфиров ароматических кислот. Они характеризуются отличной совместимостью не только с ПВХ, но и с рядом других полимеров, придают хорошие физико-механические свойства, но являются токсичными соединениями. Именно поэтому их применение постепенно вытесняется малотоксичными и нетоксичными пластификаторами.

Экологически безопасными являются сложные эфиры адипиновой кислоты, которые находят широкое применение. Однако их применение в пластикатах для кабельной продукции требует внесения в рецептуру специальных добавок антипиренов.

В данной работе приведены результаты разработки рецептуры ПВХ-композиции, обладающей низкой горючестью. В качестве пластификатора был использован разработанный нами дибутоксиэтиладипинат. В качестве антипирена - промышленный ди(2-этилгексил)фенилфосфат.

В первую очередь нами был получен сложный эфир адипиновой кислоты и оксиэтилированного бутанола со степенью оксиэтилирования 5. Подобраны условия его получения с максимальным выходом. Изучены физико-химические свойства синтезированного соединения. Составлены рецептуры ПВХ-композиций на основе полученного адипината с различными количествами ди(2-этилгексил)фенилфосфата. Представлены результаты испытаний ПВХ-пластикатов на горючесть. Показатели горючести образцов кабельного пластиката с применением разработанных пластификаторов соответствуют ГОСТ 5960-72 с изм. 3-9. Наилучшие результаты были достигнуты при применении фосфорсодержащей добавки в количестве 3\% масс. Показано, что именно малые количества ди(2-этилгексил)фенилфосфата обеспечивают противопожарные свойства.

Ключевые слова: адипиновая кислота, адипинат, антипирен, горючесть, кабельный пластикат, оксиэтилирование, оксиэтилированный бутанол, пластификатор поливинилхлорида, фосфорсодержащий пластификатор, этерификация.

Для цитирования: Мазитова А.К., Вихарева И.Н., Зарипов И.И., Мазитов Р.М., Канарейкин В.И. Разработка новой ПВХкомпозиции с пониженной горючестью // Нанотехнологии в строительстве. - 2019. - Том 11, № 6. - C. 696-705. - DOI: 10.15828/2075-8545-2019-11-6-696-705. 
Машиночитаемая информация о СС-лицензиях (HTML-код) в метаданных статьи

$<$ rel="license" href="http://creativecommons.org/licenses/by/4.0/" $><$ img alt="Creative Commons License" style="border-width:0" src="https://i.creativecommons.org/l/by/4.0/88x31.png" / ></a $><$ br / ><span xmlns:dct="http://purl.org/dc/terms/" href="http://purl.org/dc/dcmitype/Text" property="dct:title" rel="dct:type" $>$ Development of a new PVC composition with reduced flammability $</$ span $>$ by $<$ a xmlns:cc="http://creativecommons.org/ns\#" href="Nanotehnologii v stroitel'stve = Nanotechnologies in Construction. 2019, Vol. 11, no. 6, pp. 696-705. DOI:10.15828/2075-8545-2019-11-6-696-705." property="cc:attributionName" re I="cc:attributionURL">Mazitova A.K., Vikhareva I.N., Zaripov I.I., Mazitov R.M., Kanarekin V.I.</a $>$ is licensed under a $<$ a rel="license" href="http://creativecommons. org/licenses/by/4.0/" $>$ Creative Commons Attribution 4.0 International License $</ \mathrm{a}>.<\mathrm{br} />$ Based on a work at $<\mathrm{a}$ xmlns:dct="http://purl.org/dc/terms/" href="http:// nanobuild.ru/en_EN/nanobuild-6-2019/" rel="dct:source" $>$ http://nanobuild.ru/en_EN/nanobuild-6-2019/</a $>$.<br/>Permissions beyond the scope of this license may be available at $<$ a xmlns:cc="http://creativecommons.org/ns\#" href="vikhir@yandex.ru" rel="cc:morePermissions" >vikhir@yandex.ru</a $>$.

\section{INTRODUCTION}

$\mathrm{T}$ he use of plasticizers to produce plastic products be-

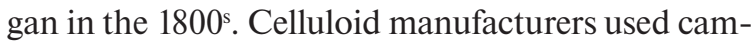
phor and castor oil for plasticization purposes. Later, in 1912, triphenyl phosphate was tested to replace camphor oil, which was the beginning of an era of ester-based plasticizers [1].

Phthalic acid esters first found use as plasticizers in 1920 and still remain the most used plasticizers [2...3]. Di-(2-ethylhexyl) phthalate, also known as dioctyl phthalate (DOF), was first used in 1930 and is a reference plasticizer.

The plastics industry is constantly growing, and the demand for plasticizers is also constantly increasing. The current market offers many types of plasticizers that can be selected for different applications according to material requirements [4...9]. Since the 1980s, use of phthalates has been limited due to their toxic effects on human health and the environment [10...11]. This fact prompted some countries to develop restrictive regulations on the use of phthalates in flexible PVC products [12...13]. There is now a tendency to replace DOFs with higher molecular weight phthalates that are more stable, have lower solubility and lower migration rate, e.g. diisonyl phthalate (DINF) or diisodecyl phthalate (DIDF).

The most promising direction of phthalate replacement is the development of plasticizers based on low-toxic and non-toxic compounds, which meets the requirements of green chemistry [14...15].

Adipic acid esters according to state standard 8728-88 are lowtoxic compounds that give PVC materials stability at low temperatures, high resistance to migration to gasoline and oils [16...18].
Additional modifying additives are required to produce PVC materials with specific properties. For example, the most effective method of reducing the combustible properties of articles is to introduce small amounts of flame retardants [19...21]. For this purpose, organophosphorus compounds are most commonly used [22...23]. Among them, di-(2-ethylhexyl) phenyl phosphate is a low-toxic compound [24...25].

Therefore, we have developed a formulation of a PVC composition comprising a novel plasticizer and flame retardant di-(2-ethylhexyl) phenyl phosphate.

\section{MAIN PART}

We have previously prepared and investigated alkoxylated alcohol adipates as novel plasticizers [26...28]. This paper describes the synthesis method and some physicochemical properties of the novel ester compound, dibutoxyethyl adipate. Test results of PVC composition containing dibutoxyethyl adipate and di-(2-ethylhexyl) phenyl phosphate are given.

The specified ester was prepared in two steps. The general scheme for the production of ethoxylated butanol adipate (degree of ethoxylation -5 ) is as follows: 
First, ethoxylated alcohol was synthesized. The final product was then esterified with adipic acid.

\section{Methods of ethoxylating of butanol}

A four-necked flask equipped with a stirrer, a thermometer, a reflux condenser and an ethylene oxide injection device is charged with a calculated amount of alcohol and a sodium hydroxide catalyst. The reactor was heated and purged with nitrogen to remove air. Ethylene oxide is then introduced gradually, controlling the rate of its supply so that the unreacted oxide is condensed in the reverse cooler and returned to the reactor «without flooding». After the ethylene oxide feed is complete, the reaction mixture is further heated and then cooled to room temperature. Catalyst is neutralized with calculated amount of sulfuric acid. The obtained mass is filtered.

\section{Method of preparing of dibutoxyethyl adipate}

Preparation of symmetrical adipate is carried out in presence of catalyst $p$-toluene sulfonic acid in medium of azeotropic water carrier of toluene, at boiling of the latter. Molar ratio of alcohol and adipic acid taken for reaction is $2.2: 1$. The reaction is controlled by the amount of water released and the acid number of the esterificate. After cooling, the reaction mixture was washed suc- cessively from the catalyst with 5\% alkali solution and water until neutral reaction. The resulting esters were dried over freshly calcined sodium sulfate and the solvent was distilled off in vacuo. Yield of the target product is 96-98\%.

The physical and chemical properties of the synthesized adipic acid ester are shown in Table 1.

The physical and chemical properties of the plasticizer were analyzed according to state standard 8728-88.

Judging by the physical and chemical properties and the study of plasticizing properties, the developed plasticizer is indeed suitable for use in PVC compositions.

A sample with a developed plasticizer was tested in a PVC composition for construction purposes, namely in cable plastics.

\section{DISCUSSION OF THE RESULTS}

The obtained sample of cable plastic brand O-40 form. OM-40 (black) was analyzed according to state standard 5960-72 with changes 1-9 «Flexible PVC for insulation and protective jackets of wires and cables». The test results are shown in Table 2.

The data given in Table 2 show that according to the main indicators (melt flow rate, thermal stability, shatter point) the obtained cable plastic complies with state standart 5960-72 with the changes 1-9 (1 class).

\section{Table 1}

Physical and chemical properties of dibutoxyethyl adipate (degree of ethoxylation - 5)

\begin{tabular}{|c|c|c|c|c|c|c|c|}
\hline \multirow{2}{*}{ Ester } & \multicolumn{7}{|c|}{ Indicators } \\
\cline { 2 - 7 } & $\begin{array}{c}\text { Degree } \\
\text { of ethoxy- } \\
\text { lation }\end{array}$ & M. w. found & $\begin{array}{c}\text { Acid num- } \\
\text { ber, } \mathbf{~ m g} \\
\mathbf{K O H} / \mathbf{g}\end{array}$ & $\begin{array}{c}\text { Ester num- } \\
\text { ber, } \mathbf{~ m g} \\
\mathbf{K O H} / \mathbf{g}\end{array}$ & $\mathbf{d}_{\mathbf{4}}{ }^{20}$ & $\mathbf{n}_{\mathbf{D}}{ }^{20}$ & $\begin{array}{c}\text { Pour point, } \\
{ }^{\circ} \mathbf{C}\end{array}$ \\
\hline $\begin{array}{l}\text { Dibutoxyethyl } \\
\text { adipate }\end{array}$ & 5 & 570 & 0.10 & 195 & 1.0380 & 1.4465 & -41 \\
\hline
\end{tabular}

Table 2

Results of testing of plasticizer in the formulation of cable plastic brand 0-40

\begin{tabular}{|l|l|l|l|}
\hline \multirow{2}{*}{\multicolumn{1}{|c|}{ Name indicators }} & \multicolumn{2}{c|}{ Plasticizer } \\
\cline { 2 - 4 } & $\begin{array}{c}\text { Norm according state } \\
\text { standart 5960-72 (1 class) }\end{array}$ & \multicolumn{1}{|c|}{ Control sample } & Dibutoxyethyl adipate \\
\hline $\begin{array}{l}\text { Melt flow rate, } \mathrm{g} / 10 \mathrm{~min} \\
\mathrm{~T}=190^{\circ} \mathrm{C}, \mathrm{P}=10 \mathrm{~kg} / \mathrm{cm}^{2}\end{array}$ & state standart $11645-73$ & 103.3 & 100.2 \\
\hline Thermal stability at $180^{\circ} \mathrm{C}, \mathrm{min}$ & state standart $14041-91$ & $2 \mathrm{~h} 15 \mathrm{~min}$ & $2 \mathrm{~h} 16 \mathrm{~min}$ \\
\hline Shatter point, ${ }^{\circ} \mathrm{C}$ & Not above -40 & Stand the test & Stand the test \\
\hline
\end{tabular}


Table 3

Indicators of combustibility of cable plastic samples brand 0-40 (sec)

\begin{tabular}{|l|c|c|c|c|}
\hline \multirow{2}{*}{ Plasticizer } & \multicolumn{4}{|c|}{ Di(2-ethylhexyl) phenyl phosphate, \% w. } \\
\cline { 2 - 5 } & $\mathbf{0}$ & $\mathbf{2}$ & $\mathbf{3}$ & $\mathbf{4}$ \\
\hline $\begin{array}{l}\text { Dibutoxyethyl adipate } \\
\text { (degree of ethoxylation - 5) }\end{array}$ & 28.0 & 25.1 & 24.3 & 24.4 \\
\hline
\end{tabular}

The effect of the amount of di(2-ethylhexyl) phenyl phosphate on the combustible properties of the cable PVC plastic samples was investigated to determine whether the PVC cable plastic composition developed could be used.

The results in Table 3 show that the values of combustible properties of samples of cable plastics obtained with dibutoxyethyl adipate and di-(2-ethylhexyl) phenyl phosphate in an amount of $3 \%$ by weight are lower than those of serially produced cable plastics (the norm according state standart 5960-72 with the changes 3-9 for cable plastic brand $\mathrm{O}-40$ is not more than $30 \mathrm{sec}$ ). A further increase in the amount of di-(2-ethylhexyl) phenyl phosphate does not improve the combustible properties of plastics.

\section{SUMMARY}

Thus, the obtained PVC composition with the developed plasticizer dibutoxyethyl adipate is not inferior to serial samples by basic physical and mechanical parameters. The addition of small amounts of phosphorus-containing flame retardant di(2-ethylhexyl) phenyl phosphate (less than $3 \%$ ) to the developed cable plastic formulation provides as low a combustion index as possible.

\section{ВВЕДЕНИЕ}

И спользование пластификаторов для изготовления изделий из пластмасс началось в 1800-х годах. Производители целлулоида применили натуральную камфору и касторовое масло для целей пластификации. Позже, в 1912 году, трифенилфосфат был испытан для замены камфорного масла, что стало началом эры пластификаторов на основе сложных эфиров [1].

Сложные эфиры фталевой кислоты впервые нашли применение в качестве пластификаторов в 1920 году и до сих пор остаются наиболее применяемыми пластификаторами [2...3]. Ди(2-этилгексил) фталат, также известный как диоктилфталат (ДОФ), впервые был использован в 1930 году и является эталонным пластификатором.

Индустрия пластмасс непрерывно растет, спрос на пластификаторы также постоянно увеличивается. Текущий рынок предлагает множество типов пластификаторов, которые можно выбрать для различных приложений в соответствии с требованиями к материалам [4...9]. С 1980-х годов использование фталатов было ограничено по причине их токсического действия на здоровье человека и окружающую среду [10...11] . Этот факт побудил некоторые страны разработать ограничительные нормы, касающиеся использования фталатов в гибких продуктах из ПВХ [12...13]. В настоящее время существует тенденция замены ДОФ на фталаты с более высокой молекулярной массой, которые более устойчивы, имеют более низкую растворимость и меньшую скорость миграции, например, диизононилфталат (ДИНФ) или диизодецилфталат (ДИДФ).

Наиболее перспективным направлением замены фталатов является разработка пластификаторов на основе малотоксичных и нетоксичных соединений, что соответствует требованиям зеленой химии [14...15].

Сложные эфиры адипиновой кислоты согласно ГОСТ 8728-88 являются малотоксичными соединениями, которые придают ПВХ-материалам стабильность при низких температурах, высокую устойчивость к миграции в бензин и масла [16...18].

Для получения ПВХ-материалов со специфическими свойствами необходимо внесение дополнительных модифицирующих добавок. Например, наиболее эффективным методом снижения горючести изделий является введение малых количеств антипиренов [19...21]. С этой целью чаще всего используют фосфорорганические соединения [22...23]. Среди них ди(2-этилгексил)фенилфосфат является малотоксичным соединением [24...25]. 
Поэтому нами разработана рецептура ПВХкомпозиции, содержащей новый пластификатор и антипирен ди(2-этилгексил)фенилфосфат.

\section{ЭКСПЕРИМЕНТАЛЬНАЯ ЧАСТЬ}

Ранее нами были получены и исследованы адипинаты оксиалкилированных спиртов в качестве новых пластификаторов [26...28]. В данной работе описан метод синтеза и некоторые физико-химические свойства нового сложноэфирного соединения дибутоксиэтиладипината. Приведены результаты испытаний ПВХ-композиции, содержащей дибутоксиэтиладипинат и ди(2-этилгексил)фенилфосфат.

Целевой сложный эфир получали в два этапа. Общая схема получения адипината оксиэтилированного бутанола (степень оксиэтилирования - 5) имеет следующий вид: ством для ввода оксида этилена, загружают расчетное количество спирта и катализатора - едкого натра. Реактор нагревают и продувают азотом для удаления воздуха. Затем постепенно вводят оксид этилена, регулируя скорость его подачи таким образом, чтобы не вступивший в реакцию оксид конденсировался в обратном холодильнике и возвращался в реактор «без захлебывания». По окончании подачи оксида этилена реакционную смесь дополнительно нагревают, а затем охлаждают до комнатной температуры. Катализатор нейтрализуют расчетным количеством серной кислоты. Полученную массу фильтруют.

\section{Методика получения дибутоксиэтиладипината}

Получение симметричного адипината осуществляют в присутствии катализатора $n$-толуолсульфо-

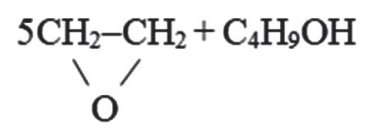

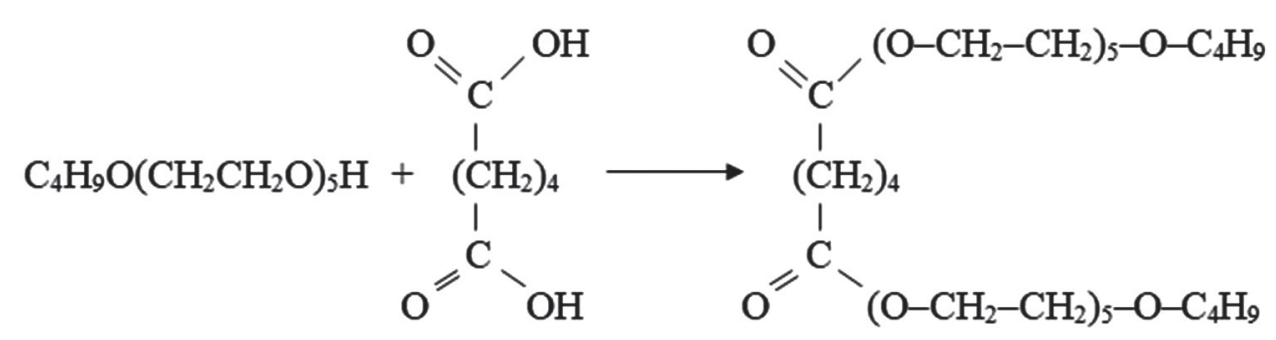

В первую очередь синтезировали оксиэтилированный спирт. Затем этерификацией его с адипиновой кислотой получали конечный продукт.

\section{Методика оксиэтилирования бутанола}

В четырехгорлую колбу, снабженную мешалкой, термометром, обратным холодильником и устрой- кислоту в среде азетропного водовыносителя толуола при кипении последнего. Мольное соотношение взятых для реакции спирта и адипиновой кислоты составляет 2.2:1. Протекание реакции контролируют по количеству выделившейся воды и кислотному числу этерификата. После охлаждения реакционную массу промывают последовательно от катализатора 5\%-ным раствором щелочи и водой до нейтральной

\section{Таблица 1}

Физико-химические свойства дибутоксиэтиладипината (степень оксиэтилирования - 5)

\begin{tabular}{|c|c|c|c|c|c|c|c|}
\hline & \multicolumn{7}{|c|}{ Показатели } \\
\hline & $\begin{array}{c}\text { Степень } \\
\text { оксиэтили- } \\
\text { рования }\end{array}$ & $\begin{array}{c}\text { М. м. } \\
\text { найдено }\end{array}$ & $\begin{array}{l}\text { К.ч., мг } \\
\text { КОН/Г }\end{array}$ & $\begin{array}{l}\text { Э.ч., мГ } \\
\text { КОН/г }\end{array}$ & $\mathrm{d}_{4}{ }^{20}$ & $\mathrm{n}_{\mathrm{D}}{ }^{20}$ & $\begin{array}{c}\text { Температу- } \\
\text { ра застыва- } \\
\text { ния, }{ }^{\circ} \mathrm{C}\end{array}$ \\
\hline $\begin{array}{l}\text { Дибутоксиэти- } \\
\text { ладипинат }\end{array}$ & 5 & 570 & 0.10 & 195 & 1,0380 & 1,4465 & -41 \\
\hline
\end{tabular}


DEVELOPMENT OF NEW POLYMER MATERIALS • РАЗРАБОTКА НОВЫХ ПОЛИМЕРНЫХ МАТЕРИАЛОВ

\section{Таблица 2}

Результаты испытаний пластификатора в рецептуре кабельного пластиката марки 0-40

\begin{tabular}{|l|l|l|l|}
\hline \multirow{2}{*}{ Наименование показателей } & \multicolumn{3}{|c|}{ Пластификатор } \\
\cline { 2 - 4 } & $\begin{array}{c}\text { Норма по ГОСТ 5960-72 } \\
\text { с изм. 1-9 (1 сорт) }\end{array}$ & Контрольный образец & $\begin{array}{c}\text { Дибутоксиэтилади- } \\
\text { пинат }\end{array}$ \\
\hline $\begin{array}{l}\text { ПТР, г } / 10 \text { мин при } 190^{\circ} \mathrm{C}, \\
\mathrm{P}=10 \text { кгс } / \mathrm{cm}^{2}\end{array}$ & ГОСТ $11645-73$ & 103,3 & 100,2 \\
\hline $\begin{array}{l}\text { Термостабильность } \\
\text { при } 180^{\circ} \mathrm{C}, \text { мин }\end{array}$ & ГОСТ $14041-91$ & 2 ч 15 мин & 2 м 16 мин \\
\hline Температура хрупкости, оС & не выше -40 & выдерж. & выдерж. \\
\hline
\end{tabular}

Таблица 3

Показатели горючести образцов кабельных пластикатов марки 0-40 (c)

\begin{tabular}{|c|c|c|c|c|}
\hline \multirow{2}{*}{ Пластификатор } & \multicolumn{4}{|c|}{ Ди(2-этилгексил)фенилфосфат, \% масс. } \\
\cline { 2 - 5 } & $\mathbf{0}$ & $\mathbf{2}$ & $\mathbf{3}$ & $\mathbf{4}$ \\
\hline $\begin{array}{l}\text { Дибутоксиэтиладипинат (сте- } \\
\text { пень оксиэтилирования - 5) }\end{array}$ & 28,0 & 25,1 & 24,3 & 24,4 \\
\hline
\end{tabular}

реакции. Полученные сложные эфиры сушат над свежепрокаленным сульфатом натрия и отгоняют растворитель под вакуумом. Выход целевого продукта составляет 96-98\%.

Физико-химические свойства синтезированного эфира адипиновой кислоты приведены в табл. 1.

Физико-химические показатели пластификатора анализировали согласно ГОСТ 8728-88.

Судя по физико-химическим свойствам и исследованию пластифицирующих свойств, разработанный пластификатор действительно пригоден для использования в ПВХ-композициях.

Образец с разработанным пластификатором был испытан в ПВХ-композиции строительного назначения, а именно в кабельных пластикатах.

\section{ОБСУЖДЕНИЕ РЕЗУЛЬТАТОВ}

Полученный образец кабельного пластиката марки О-40 рец. ОМ-40 (черный) анализировали по ГОСТ 5960-72 с изм. 1-9 «Пластикат поливинилхлоридный для изоляции и защитных оболочек проводов и кабелей». Результаты испытаний приведены в табл. 2.

Приведенные в табл. 2 данные показывают, что по основным показателям (температура хрупкости, термостабильность, ПТР) полученный кабельный пластикат соответствует ГОСТ 5960-72 с изм. 1-9 (1 сорт).
Для определения возможности использования разработанной ПВХ-композиции кабельного пластиката было исследовано влияние количества ди(2этилгексил)фенилфосфата на показатели горючести образцов кабельных ПВХ-пластикатов.

Приведенные в табл. 3 результаты показывают, что образцы кабельных пластикатов с применением дибутоксиэтиладипината и ди(2-этилгексил)фенилфосфата в количестве 3 \% масс. по показателям горючести обеспечивают более низкие значения, чем серийно выпускаемые (норма по ГОСТ 5960-72 с изм. 3-9 для кабельного пластиката марки О-40 составляет не более 30 с). Дальнейшее увеличение количества ди(2-этилгексил)фенилфосфата не приводит к улучшению показателей горючести пластикатов.

\section{ВЫВОДЫ}

Таким образом, полученная ПВХ-композиция с разработанным пластификатором дибутоксиэтиладипинат (степень оксиэтилирования - 5) по основным физико-механическим показателям не уступает серийным образцам. Добавление небольших количеств фосфорсодержащего антипирена ди(2этилгексил)фенилфосфата (менее 3\%) в разработанную рецептуру кабельных пластикатов обеспечивает максимально сниженные значения показателей горючести. 


\section{REFERENCES}

1. Zefirova O.N. Kratkii kurs istorii i metodologii khimii [Short course on chemistry history and methodology]. Moscow. Anabasis, 2007. 140 p.

2. Rahman M., Brazel C.S. The plasticizer market: an assessment of traditional plasticizers and research trends to meet new challenges. Prog. Polym. Sci. 2004, Vol. 29, no. 12, pp. 1223-1248.

3. Mazitova A.K., Nafikova R.F., Aminova G.K. Plastifikatory polivinilkhlorida [Polyvinylchloride plasticizers]. Nauka i epokha: monografiya; pod obshchei red. prof. O.I. Kirikova. Voronezh. 2011, pp. 277-297.

4. Fedorenko N.P. Universalnyi plastik (Polivinilkhlorid) [Universal plastic (Polyvinylchloride)]. Moscow, Science, 1966. 119 p. (In Russian).

5. Wilkes C.E., Summers J.W., Daniels C.A., Berard M.T. PVC Handbook. Hanser Publications, 2005. 723 p.

6. Maskova A.R., Aminova G.K., Rol'nik L.Z., Faizullina G.F., Mazitova A.K. Ftalaty oksialkilirovannykh spirtov [Oxyalkylated alcohols phthalates]. Nanotekhnologii v stroitel'stve $=$ Nanotechnologies in Construction. 2019, Vol. 11, no. 1, pp. 52-71, DOI: $10.15828 / 2075-8545-2019-11-1-52-71$.

7. Godwin A.D. Plasticizers. Applied Plastics Engineering Handbook Elsevier, 2017. 784 p.

8. Mazitova A.K., Aminova G.K., Maskova A.R., Cabitov I.N., Nedoseko I.V. Novye plastifikatory polivinilkhlorida [New plasticizers of polyvinylchloride]. Nanotekhnologii v stroitel'stve $=$ Nanotechnologies in Construction. 2017, Vol. 9, no. 6, pp. 168-180, DOI: $10.15828 / 20758545-2017-9-6-168-180$.

9. Mazitova A.K., Aminova G.K., Maskova A.R., Yagafarova G. G., Mazitov R.M. Novye plastifikatory dlya PVKh-kompozitsii stroitel'nogo naznacheniya [New plasticizers for PVC construction compositions]. Nanotekhnologii v stroitel'stve $=$ Nanotechnologies in Construction. 2017, Vol. 9, no. 4, pp. 48-63, DOI: 10.15828/2075-8545-2017-9-4-48-63.

10. Sunny M.C., Ramesh P., George K.E. Use of polymeric plasticizers in polyvinyl chloride to reduce conventional plasticizer migration for critical applications. J. Elastomers Plast. 2004, Vol. 36, no. 1, pp. 19-31.

11. Hakkarainen M. Migration of monomeric and polymeric PVC plasticizers. Adv. Polym. Sci. 2008, Vol. 211, no. 1, pp. $159-185$.

12. Pielichowski K.S., wierz-Motysia B. Influence of polyesterurethane plasticizer on the kinetics of poly(vinyl chloride) decomposition process. J. Therm. Anal. Calorim. 2006, Vol. 83, no. 1, pp. 207-212.

13. Fenollar O., Sanchez-Nacher L., Garcia-Sanoguera D., Lopez J., Balart R. The effect of the curing time and temperature on final properties of flexible PVC with an epoxidized fatty acid ester as natural-based plasticizer. J. Mater. Sci. 2009, Vol. 44, no. 14 , pp. 3702-3711.

14. Pedersen G.A., Jensen L.K., Fankhauser A., Biedermann S., Petersen J.H., Fabech B. Migration of epoxidized soybean oil (ESBO) and phthalates from twist closures into food and enforcement of the overall migration limit. Food Addit. Contam. 2008, Vol. 25, no. 4, pp. 503-510.

15. Tickner J.A., Schettler T., Guidotti T., McCally M., Rossi M. Health risks posed by use of di-2-ethylhexyl phthalate (DEHP) in PVC medical devices: a critical review. Am. J. Ind. Med. 2001, Vol. 39, no. 1, pp. 100-111.

16. Godwin A.D. Plasticizer selection and phthalate alternatives. Presented at Society of Plastic Engineers Vinyl Division Technical Conference. Vinyltec 2008, Chicago, 2008.

17. Sadieva N.F., Nasibova G.G., Iskenderova S.A., Zeinalov E.B., Asadova Sh.N., Nuriev L.G., Agaev B.K. Effektivnye plastifikatory dlya polivinilkhlorida [Effective plasticizers for polyvinyl chloride]. Plasticheskie massy = Plastics. 2018, no. 3-4, pp. 17-18.

18. Jain K.K., Fatma K., Saroop M. Popular Plast. Packaging, 1998, Vol. 43, no. 11, pp. 75-82.

19. Sapaev Kh.Kh., Musov I.V., Khashirova S.Yu., Bashorov M.T., Shogenov V.N., Kushkhov Kh.B., Mikitaev A.K., Zaikov G.E. Izuchenie vliyaniya razlichnykh plastifikatorov na svoistva polivinilkhloridnogo plastikata [Study of the effect of various plasticizers on the properties of polyvinyl chloride plastic]. Vestnik tekhnologicheskogo universiteta $=$ Bulletin of the technological university. 2015, Vol. 18, no. 9, pp. 102-105.

20. Khalturinskii N.A., Berlin A.A., Popova T.V. Gorenie polimerov i mekhanizmy deistviya antipirenov [Polymer burning and flame retardant mechanisms]. Uspekhi khimii = Achievements of chemistry. 1984, Vol. 53, no. 2, 326 p.

21. Mazitova A.K., Maskova A.R., Nafikova R.F., Aminova G.K. Ispol'zovanie dobavok pri poluchenii kabel'nykh plastikatov [Use of additives in the production of cable plastics]. Bashkirskii khimicheskii zhurnal = Bashkir chemical journal. 2017, Vol. 24, no. 3 , pp. $50-53$.

22. Aseeva R.M., Zaikov G.E. Gorenie polimernykh materialov [Burning of polymeric materials]. Moscow. Science, 1981. 280 p.

23. Plotnikova G.V., Egorov A.N. Dostupnye fosfororganicheskie soedineniya kak zamedliteli goreniya [Available organophosphorus compounds as flame retardants]. Pozharovzryvobezopasnost = Fire and explosion safety. 2003, no. 6, pp. 26-29.

24. Tager A.A. Fizikokhimiya polimerov [Physical chemistry of polymers]. 3-e izd. Moscow. Khimiya, 1978, 544 p.

25. Suvorova A.I. and others. Vysokomolekulyarnye soedineniya [High-molecular compounds]. 1966, Vol. 8, pp. $1692-1697$.

26. Vikhareva I.N., Builova E.A., Gatiyatullina D.R., Arslanov V.R., Gilem'yanov D.A., Mazitova A.K. Sintez i svoistva slozhnykh efirov adipinovoi kisloty [Synthesis and properties of adipic acid esters]. Bashkirskii khimicheskii zhurnal $=$ Bashkir chemical journal. 2019, Vol. 26, no. 2, pp. 33-36.

27. Mazitova A.K., Vikhareva I.N., Aminova G.K., Timofeev A.A., Builova E.A., Distanov R. Sh. Issledovanie vliyaniya kolichestva dobavok na svoistva efirov adipinovoi kisloty [Investigation of the effect of the amount of additives on the properties of adipic acid esters]. Nanotekhnologii v stroitel'stve = Nanotechnologies in construction. 2019, Vol. 11, no. 4, pp. 437-446.

28. Vikhareva I.N., Il'yasova A.D., Likhacheva O.G., Zapotylok G.Yu., Mazitova A. K. Di-(2-etilgeksiloksi)etiladipinaty [Di-(2-ethylhexyloxy)adipates]. Bashkirskii khimicheskii zhurnal = Bashkir chemical journal. 2019, Vol. 26, no. 2, pp. 90-91. 


\section{СПИСОК ЛИТЕРАТУРЫ}

1. Зефирова О.Н. Краткий курс истории и методологии химии. - М.: Анабасис, 2007. - 140 с.

2. Rahman M., Brazel C.S. The plasticizer market: an assessment of traditional plasticizers and research trends to meet new challenges // Prog. Polym. Sci. - 2004. - Vol. 29. - P. 1223-1248.

3. Мазитова А.К., Нафикова Р.Ф., Аминова Г.К. Пластификаторы поливинилхлорида / Наука и эпоха: монография; под общей ред. проф. О.И. Кирикова. - Воронеж, 2011. - С. 277-297.

4. Федоренко Н.П. Универсальный пластик (Поливинилхлорид). - М.: Наука, 1966. - 119 с.

5. Wilkes C.E., Summers J.W., Daniels C.A., Berard M.T. PVC Handbook / Hanser Publications, 2005. - 723 p.

6. Маскова А.Р., Аминова Г.К., Рольник Л.З., Файзуллина Г.Ф., Мазитова А.К. Фталаты оксиалкилированных спиртов // Нанотехнологии в строительстве. - 2019. - Том 11, № 1. - C. 52-71. - DOI: 10.15828/2075-8545-2019-11-1-52-71.

7. Godwin A.D. Plasticizers /Applied Plastics Engineering Handbook Elsevier, 2017. - 784 p.

8. Мазитова А.К., Аминова Г.К., Маскова А.Р., Сабитов И.Н., Недосеко И.В. Новые пластификаторы поливинилхлорида // Нанотехнологии в строительстве. - 2017. - Том 9, № 6. - С. 168-180. - DOI: 10.15828/20758545-2017-9-6-168-180.

9. Мазитова А.К., Аминова Г.К., Маскова А.Р., Ягафарова Г. Г., Мазитов Р.М. Новые пластификаторы для ПВХкомпозиций строительного назначения // Нанотехнологии в строительстве. - 2017. - Том 9, № 4. - C. 48-63. - DOI: 10.15828/2075-8545-2017-9-4-48-63.

10. Sunny M.C., Ramesh P., George K.E. Use of polymeric plasticizers in polyvinyl chloride to reduce conventional plasticizer migration for critical applications // J. Elastomers Plast. 2004. - Vol. 36, № 1. - P. 19-31.

11. Hakkarainen M. Migration of monomeric and polymeric PVC plasticizers // Adv. Polym. Sci. - 2008. - Vol. 211. P. 159-185.

12. Pielichowski K., S. wierz-Motysia B. Influence of polyesterurethane plasticizer on the kinetics of poly(vinyl chloride) decomposition process // J. Therm. Anal. Calorim. - 2006. - Vol. 83, № 1. - P. 207-212.

13. Fenollar O., Sanchez-Nacher L., Garcia-Sanoguera D., Lopez J., Balart R. The effect of the curing time and temperature on final properties of flexible PVC with an epoxidized fatty acid ester as natural-based plasticizer // J. Mater. Sci. - 2009. - Vol. 44, № 14. - P. 3702-3711.

14. Pedersen G.A., Jensen L.K., Fankhauser A., Biedermann S., Petersen J.H., Fabech B. Migration of epoxidized soybean oil (ESBO) and phthalates from twist closures into food and enforcement of the overall migration limit // Food Addit. Contam. 2008. - Vol. 25, № 4. - P.503-510.

15. Tickner J.A., Schettler T., Guidotti T., McCally M., Rossi M. Health risks posed by use of di-2-ethylhexyl phthalate (DEHP) in PVC medical devices: a critical review // Am. J. Ind. Med. - 2001. - Vol. 39. - P. 100-111.

16. Godwin A.D. Plasticizer selection and phthalate alternatives // Presented at Society of Plastic Engineers Vinyl Division Technical Conference. Vinyltec 2008. - Chicago, 2008.

17. Садиева Н.Ф., Насибова Г.Г., Искендерова С.А., Зейналов Э.Б., Асадова Ш.Н., Нуриев Л.Г., Агаев Б.К. Эффективные пластификаторы для поливинилхлорида // Пластические массы. - 2018. - № 3-4. - С. 17-18.

18. Jain K.K., Fatma K., Saroop M. // Popular Plast. Packaging. - 1998. - Vol. 43. - № 11. - P. 75-82.

19. Сапаев Х.Х., Мусов И.В., Хаширова С.Ю., Башоров М.Т., Шогенов В.Н., Кушхов Х.Б., Микитаев А.К., Заиков Г.Е. Изучение влияния различных пластификаторов на свойства поливинилхлоридного пластиката // Вестник технологического университета. - 2015. - Том 18, № 9. - С. 102-105.

20. Халтуринский Н.А., Берлин А.А., Попова Т.В. Горение полимеров и механизмы действия антипиренов // Успехи химии. - 1984. - Т. 53, № 2. - С. 326.

21. Мазитова А.К., Маскова А.Р., Нафикова Р.Ф., Аминова Г.К. Использование добавок при получении кабельных пластикатов // Башкирский химический журнал. - 2017. - Том 24, № 3. - С. 50-53.

22. Асеева Р.М., Заиков Г.Е. Горение полимерных материалов. - М.: Наука, 1981. - 280 с.

23. Плотникова Г.В., Егоров А.Н. Доступные фосфорорганические соединения как замедлители горения // Пожаровзрывобезопасность. - 2003. - № 6. - С. 26-29.

24. Тагер А.А. Физикохимия полимеров / 3-е изд. - М.: Химия, 1978. - 544 с.

25. Суворова А.И. и др. Высокомолекулярные соединения. - 1966. - Том 8. - С. 1692-1697.

26. Вихарева И.Н., Буйлова Е.А., Гатиятуллина Д.Р., Арсланов В.Р., Гилемьянов Д.А., Мазитова А.К. Синтез и свойства сложных эфиров адипиновой кислоты. - Башкирский химический журнал. - 2019. - Т. 26, № 2. - С. $33-36$.

27. Мазитова А.К., Вихарева И.Н., Аминова Г.К., Тимофеев А.А., Буйлова Е.А., Дистанов Р. Ш. Исследование влияния количества добавок на свойства эфиров адипиновой кислоты // Нанотехнологии в строительстве. - 2019. - Том 11, № 4. - С. 437-446.

28. Вихарева И.Н., Ильясова А.Д., Лихачёва О.Г., Запотылок Г.Ю., Мазитова А.К. Ди-(2-этилгексилокси)этиладипинаты. - Башкирский химический журнал. - 2019. - Т. 26, № 2. - С. 90-91. 


\section{INFORMATION ABOUT THE AUTHORS}

Aliya K. Mazitova, Doctor of Chemistry, Professor, Head of Applied and Natural Sciences Department, Ufa State Petroleum Technological University; Mendeleev St., 195, Ufa, Bashkortostan Republic, Russia, 450080; elenaasf@yandex.ru;

Irina N. Vikhareva, Assistant, Applied and Natural Sciences Department, Ufa State Petroleum Technological University; Mendeleev St., 195, Ufa, Bashkortostan Republic, Russia, 450080; vikhir@yandex.ru;

II'naz I. Zaripov, undergraduate, Applied and Natural Sciences Department, Ufa State Petroleum Technological University; Mendeleev St., 195, Ufa, Bashkortostan Republic, Russia, 450080; ilnaz.zaripov1996@mail.ru;

Ruslan M. Mazitov, PhD in Engineering, Associate Professor of history and cultural studies,

Ufa State Petroleum Technological University; Kosmonavtov St., 1, Ufa, Bashkortostan Republic, Russia, 450062; mazitovps@mail.ru,

Vladimir I. Kanareikin, PhD in Engineering, Associate Professor, Applied and Natural Sciences Department, Ufa State Petroleum Technological University; Mendeleev St., 195, Ufa, Bashkortostan Republic, Russia, 450080; kanareikina1948@mail.ru

\section{ИНФОРМАЦИЯ ОБ АВТОРАХ}

Мазитова Алия Карамовна, д.Х.н., проф., зав. каф. «Прикладные и естественнонаучные дисциплины», ФГБОУ ВО «Уфимский государственный нефтяной технический университет»; ул. Менделеева, 195, г. Уфа, Республика Башкортостан, Россия, 450080; elenaasf@yandex.ru;

Вихарева Ирина Николаевна, ассистент каф. «Прикладные и естественнонаучные дисциплины», ФГБОУ ВО «Уфимский государственный нефтяной технический университет»; ул. Менделеева, 195, г. Уфа, Республика Башкортостан, Россия, 450080; vikhir@yandex.ru;

Зарипов Ильназ Ильгизович, магистрант каф. «Прикладные и естественнонаучные дисциплины», ФГБОУ ВО «Уфимский государственный нефтяной технический университет»; ул. Менделеева, 195, г. Уфа, Республика Башкортостан, Россия, 450080; ilnaz.zaripov1996@mail.ru;

Мазитов Руслан Мидхатович, к.т.н., доцент кафедры истории и культурологии, ФГБОУ ВО «Уфимский государственный нефтяной технический университет»; ул. Космонавтов, 1, г. Уфа, Республика Башкортостан, Россия, 450062; mazitovps@mail.ru;

Канарейкин Владимир Иванович, к.т.н., доцент каф. «Прикладные и естественнонаучные дисциплины», ФГБОУ ВО «Уфимский государственный нефтяной технический университет»; ул. Менделеева, 195,

г. Уфа, Республика Башкортостан, Россия, 450080; kanareikina1948@mail.ru 